\title{
Turbidity of Landlocked Fall Chinook Salmon Ovarian Fluid in Relation to Egg Survival
}

\author{
Patrick A. Nero, Michael E. Barnes* and Matthew M. Wipf \\ McNenny State Fish Hatchery, South Dakota Department of Game, Fish and Parks, 19619 Trout Loop, Spearfish, South \\ Dakota 57783, USA
}

\begin{abstract}
This study evaluated the use of ovarian fluid turbidity as a potential indicator of landlocked fall Chinook Salmon Oncorhynchus tshawytscha egg survival. A total of 21 females were spawned, with nine of the spawns containing between one and ten broken eggs per spawn. Ovarian fluid turbidity ranged from 55.1 to 159 nephelometric turbidity units (NTU), and egg survival to the eyed-stage of egg development ranged from 0 to $68 \%$. There was no significant correlation between ovarian fluid turbidity and egg survival. Mean survival of eggs from the spawns containing broken eggs was $12.3 \%$, which was significantly lower than the $32.9 \%$ mean survival from spawns without broken eggs. These results indicate ovarian fluid turbidity cannot be used to predict egg survival in spawns of landlocked fall Chinook Salmon, but the presence of even a small number of broken eggs may be indicative of poor survival to the eyed-egg stage of development.
\end{abstract}

Keywords: Chinook Salmon, Oncorhynchus tshawytscha, turbidity, spawning, ovarian fluid, eggs.

\section{INTRODUCTION}

Eggs from landlocked fall Chinook Salmon Oncorhynchus tshawytscha in Lake Oahe, South Dakota, typically exhibit poor, but highly variable, survival during hatchery incubation $[1,2]$. Because of the inefficiencies that occur from incubating eggs whose survival is extremely low or non-existent, techniques to predict egg survival during spawning have been evaluated in this population. Barnes et al. [3] found no correlations between egg survival and ovarian fluid specific gravity, $\mathrm{pH}$, conductivity, or total ovarian fluid volume. Discarding spawns with an estimated $10 \%$ or more overripe eggs has been an effective approach, but is a rough tool at best [4], and is only useful in those spawns which contain overripe eggs.

Turbidity is the measurement of the amount of suspended particles in a liquid solution [5]. Wojtczak et al. [6] reported that poor quality Rainbow Trout $O$. mykiss eggs created turbidity when added to water. Tabrizi et al. [7] observed that egg mortality was associated with the turbidity of ovarian fluid mixed with water in the spawns of Caspian Brown Trout Salmotruttacaspius. Turbidity of the ovarian fluid itself, without the addition of water, has not previously been examined as an indicator of egg quality. Quantitative turbidity measurements of ovarian fluid or ovarian fluid mixed with water have also not been reported; Tabrizi et al. [6] and Wojtczak et al. [7] only qualitatively assessed fertilization solution turbidity. In addition, ovarian fluid turbidity has not been previously studied in landlocked fall Chinook Salmon.

\footnotetext{
*Address correspondence to this author at the State Fish Hatchery, South Dakota Department of Game, Fish and Parks, 19619 Trout Loop, Spearfish, South Dakota 57783, USA; Tel: (605) 642-6920, Fax: (605) 642-6921;
}

E-mail: Mike.Barnes@state.sd.us
Thus, the objective of this study paper was to evaluate the possible use of quantitative ovarian fluid turbidity measurements as indicators of landlocked fall Chinook Salmon egg survival.

\section{MATERIALS AND METHODOLOGY}

Spawning of landlocked fall Chinook Salmon from Lake Oahe, South Dakota, occurred on October 16, 2012, at Whitlocks Spawning Station, near Gettysburg, South Dakota. Milt was collected from males, pooled in a container, and kept cool until used. Eggs were pneumatically expressed from each female using compressed oxygen at low pressure into a mesh net, allowing the ovarian fluid to be drained, collected, and measured. A total of 21 females were spawned, with spawns from nine of the females contained a small number of broken eggs. Fewer than 10 broken eggs per spawn were observed, and they were broken prior to the spawning process (i.e. within the body cavity of the female). Turbidity of ovarian fluid was measured in nephelometric turbidity units (NTUs) using a LaMotte 2020e turbidity meter (LaMotte Company, Chestertown, Maryland) and the total amount of ovarian fluid measured to the nearest $\mathrm{mL}$. After turbidity measurements, the ovarian fluid was added back to the eggs. Lake water was then added to the spawn to activate the sperm for fertilization. After $2 \mathrm{~min}$, the eggs were rinsed with lake water and allowed to water harden in lake water for at least one $\mathrm{h}$ prior to shipment.

Water-hardened eggs were transported $4 \mathrm{~h}$ to McNenny State Fish Hatchery, rural Spearfish, South Dakota. Upon arrival, the eggs were disinfected in a solution of $100 \mathrm{mg} / \mathrm{L}$ buffered free iodine for $10 \mathrm{~min}$. Eggs were inventoried using the water displacement method [8] and individual spawns were placed into separate vertical flow incubation trays (Marisource, Payallup, Washington). Well water (11 C; total 
Table 1. Mean (SE) Spawning Female, Ovarian Fluid, and Egg Parameters Collected from Landlocked Fall Chinook Salmon. Means with Different Letters within a Row are Significantly Different $(N=21, P<0.05)$

\begin{tabular}{|c|c|c|c|}
\hline & \multicolumn{2}{|c|}{ Broken Eggs in Spawn } & Overall \\
\hline & Yes & No & \\
\hline \hline Female length (mm) & $647(23)$ & $667(15)$ & $659(13)$ \\
\hline Female weight (g) & $2,392(369)$ & $2,460(200)$ & $2,431(190)$ \\
\hline Ovarian fluid (ml) & $60(17)$ & $48(9)$ & $53(9)$ \\
\hline Egg size (eggs/ml) & $5.9(0.6)$ & $5.5(0.3)$ & $5.7(0.3)$ \\
\hline Fecundity (\# of eggs) & $2,394(249)$ & $2,202(222)$ & $2,289(163)$ \\
\hline Turbidity (NTU) & $99.5(9.7)$ & $111.1(11.8)$ & $106.1(7.9)$ \\
\hline Eyed egg survival (\%) & $12.3(0.1) \mathrm{z}$ & $32.9(0.1) \mathrm{y}$ & $24.1(0.1)$ \\
\hline
\end{tabular}

${ }^{1}$ Nephelometric turbidity units

hardness at $\mathrm{CaCO} 3,360 \mathrm{mg} / \mathrm{L}$; alkalinity as $\mathrm{CaCO} 3,210$ $\mathrm{mg} / \mathrm{L} ; \mathrm{pH}$ 7.6; total dissolved solids, $390 \mathrm{mg} / \mathrm{L}$ ) at $12 \mathrm{~L} / \mathrm{min}$ was used throughout incubation. Daily formalin treatments using Paracide-F (37\% formaldehyde, 6 to $14 \%$ methanol, Western Chemical, Ferndale, Washington) at a concentration of $1,667 \mathrm{mg} / \mathrm{L}$ for $15 \mathrm{~min}$ were administered with a Masterflex model 7524-00 microprocessor peristaltic pump (ColeParmer Instrument Company, Chicago, Illinois) once a day for four weeks. Dead eggs were removed on incubation day 28 (eyed egg stage) and the remaining viable eyed eggs were reinventoried by water displacement. Percent survival was determined by dividing the number of eyed eggs by the initial number of eggs and multiplying this amount by 100 .

Data were analyzed with t-tests, and regression and correlation analysis using the SPSS (9.0) statistical analysis program. Significance was predetermined at $P \leq 0.05$. All mortality percentage data were arcsine-square root transformed prior to analysis to stabilize the variances [9].

\section{RESULTS AND DISCUSSION}

Egg survival to the eyed stage varied from $0 \%$ to $67.6 \%$, with a mean of $24.1 \%$ (Table 1). Spawn from three females had $0 \%$ survival, and three had survival below $1 \%$. Mean survival of eggs from the spawns containing broken eggs was $12.3 \%$, which was significantly lower $(P=0.048)$ than the $32.9 \%$ mean survival from spawns without broken eggs. Negative effects on salmon egg survival from broken eggs were also noted by Carl [10] and suggested by Wojtczak et al. [6], while Wilcox et al. [11] found that egg contents present in the fertilization media reduced fertilization rates in Coho Salmon O. kisutch. Tabrizi et al. [7] also noted that egg mortality was higher in the spawns of Caspian brown trout containing broken eggs. Although Wipf et al. [12] did not report the occurrence of broken eggs, they did observe that the absence of ovarian fluid, and its chemical constituents, improved subsequent egg survival. The change in ovarian fluid chemical composition and subsequent turbidity due to the rupturing of egg membranes may be responsible for the changes in egg survival observed in this study. Differences in ovarian fluid composition have been shown to affect sperm motility, fertilization rates, and egg survival [13].

The broken eggs were not a result of the egg extrusion and were observed to be broken immediately upon expulsion from the female. It is possible that egg breakage occurred earlier in the spawning process, particularly when the females were handled during netting, anesthesia, and ovulation checks. Handling of spawning females can be a factor in subsequent egg mortality $[14,15]$.

Ovarian fluid turbidity ranged from 11 to 175 NTU, with a mean of 53 NTU. There was no significant difference in ovarian fluid turbidity between spawns containing broken eggs compared to spawns without broken eggs. Ovarian fluid turbidity and subsequent egg survival exhibited no relationship (Fig. 1). Turbidity was not correlated to female length, female weight, egg size, or fecundity.

Both Wojtczak et al. [6] and Tabrizi et al. [7] examined turbidity after the addition of clean hatchery water to ovarian

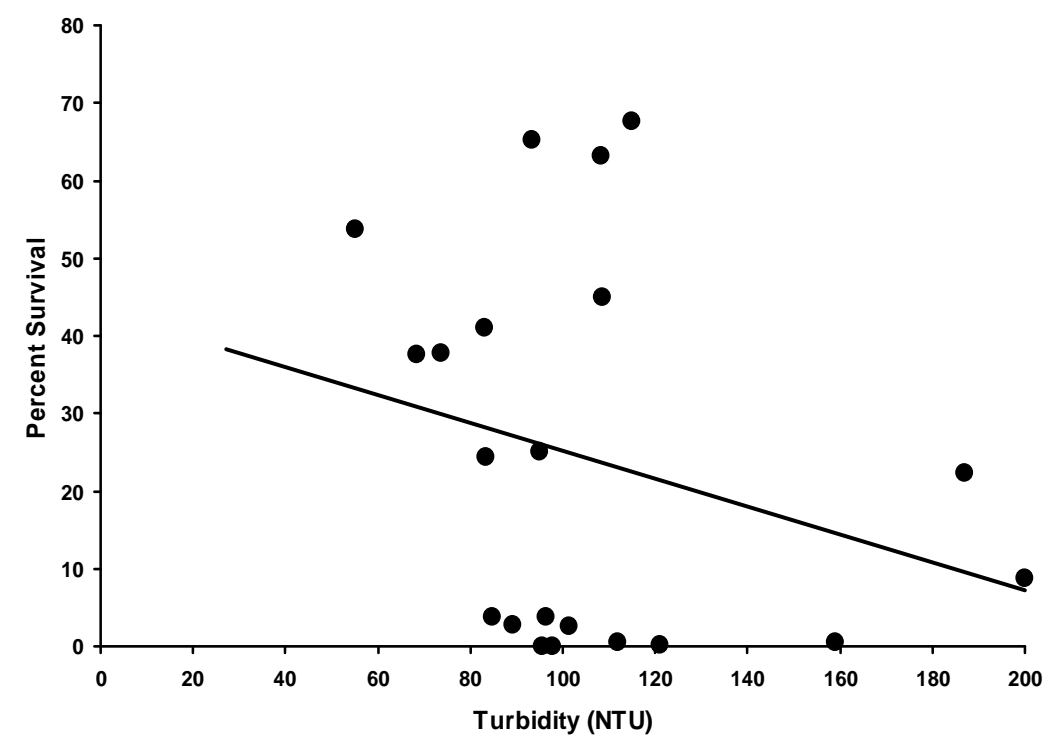

Fig. (1). Ovarian fluid turbidity (NTU) from spawning fall Chinook Salmon in relation to subsequent eyed-egg survival (\%). 
fluid, whereas the present study took turbidity measurements directly from the ovarian fluid itself. Salmon spawning operations on Lake Oahe use lake water for sperm activation because of the difficulty in transporting clean hatchery water. Turbidity in lake water varies due to soil erosion [16], resuspension of bottom sediments [16], phytoplankton [17], fine woody particles [18], and weather conditions [19]. The variation in Lake Oahe water turbidity makes it difficult to use the turbidity of fertilization solutions containing lake water of fluctuating turbidity and ovarian fluid as a predictor of egg survival. This study, examining just the turbidity of the ovarian fluid itself, shows that if broken eggs are present, ovarian, fluid turbidity can provide some basis for the retention or disposal of selected spawns.

The turbidity measurements observed in this study may be unique to Chinook Salmon and may even be unique to the Lake Oahe salmon population. Differences in ovarian fluid chemical composition have been observed among different fish species [20], making it likely that ovarian fluid turbidity may vary as well.

Measurements of ovarian fluid characteristics to predict future egg survival during spawning have produced mixed results. Lahnsteiner et al. [21] observed a significant correlation between egg viability and ovarian fluid $\mathrm{pH}$, protein levels, aspartate aminotransferase activity, and $\beta$-Dglucuronidase activity. In contrast, Barnes et al. [3] found no relationship between $\mathrm{pH}$ of ovarian fluid and egg viability in Lake Oahe fall Chinook Salmon. The results of this study indicate that ovarian fluid turbidity cannot be generally used to predict the survival of landlocked fall Chinook Salmon eggs. However, the presence of broken eggs may be an indicator of egg quality, particularly as it relates to survival to the eyed-egg stage.

\section{CONFLICT OF INTEREST}

The authors confirm that this article content has no conflicts of interest.

\section{ACKNOWLEDGEMENTS}

The authors thank Amanda Davis, Eric Krebs, Raesha Ray, and Sarah Zimmerman for their assistance with this study.

\section{REFERENCES}

[1] Barnes ME, Hanten RP, Cordes RJ, Sayler WA, Carreiro J. Reproductive performance of inland fall chinook salmon. $\mathrm{N}$ Am J Aquac $2000 ; 62: 203-11$
[2] Wipf MM, Barnes ME. Parental male effects on landlocked fall Chinook salmon progeny survival. N Am J Aquac 2012; 74(4): 443-8.

[3] Barnes ME, Sayler WA, Cordes RJ, Hanten RP. Potential indicators in landlocked fall chinook salmon spawn with or without the presence of overripe eggs. N Am J Aquac 2003; 65: 49-55.

[4] Barnes ME, Hanten RP, Sayler WA, Cordes RJ. Viability of inland fall chinook salmon spawn containing overripe eggs and the reliability of egg viability estimates. N Am J Aquac 2000; 62: 237-9.

[5] Wetzel RG. Limnology Lake and River Ecosystems. $3^{\text {rd }}$ ed. San Diego: Academic Press 2001.

[6] Wojtczak MR, Kowalski S, Dobosz K, et al. Assessment of water turbidity for evaluation of Rainbow Trout (Oncorhynchus mykiss) egg quality. Aquaculture 2001; 242: 617-24.

[7] Tabrizi H, Nezami SA, Lorestani R, Shamspour S. Broken egg influence on fertilization capacity and viability of eggs, turbidity and $\mathrm{pH}$ of ovarian fluid and fertilization water in the endangered Caspian brown trout, Salmo trutta Caspius. Int J Biol 2011; 3: 1616.

[8] Piper RG, McElwain IB, Orme LE, McCraren JP, Fowler LG, Leonard JR. Fish Hatchery Management. Washington: U.S. Fish and Wildlife Service 1982.

[9] Kuehl RO. Design of experiments: statistical principles of research design and analysis. $2^{\text {nd }}$ ed. California: Brookes/Cole 2000.

[10] Carl GC. Beware of the broken eggs! A possible cause of heavy losses of salmon eggs. Prog Fish Cult 1941; 53: 30-1.

[11] Wilcox KW, Stoss J, Donaldson EM. Broken eggs as a cause of infertility of coho salmon gametes. Aquaculture 1984; 40: 77-87.

[12] Wipf MM, Barnes ME, Durben DJ. An evaluation of two egg collection and two fertilization techniques during landlocked fall Chinook salmon spawning. N Am J Aquac 2011; 73: 339-42.

[13] Rosengrave P, Taylor H, Montgomerie R, Metcalf V, McBride K, Gemmell NJ. Chemical composition of seminal fluid and ovarian fluids of chinook salmon (Oncorhyncus tshawytscha) and their effects on sperm motility traits. Comp Biochem Physiol Part A Mol Integr Physiol 2009; 152(1) 123-9.

[14] Barnes ME, Lott JP, Sayler WA, Cordes RJ. Practical observations on the use of eggs from electroshocked females during spawning of inland fall Chinook Salmon. N Am J Aquac 1999; 61: 162-6.

[15] Sminov IA. The effect of mechanical agitation on developing eggs of the pinksalmon Oncorhynchusgorbuscha (Walbaum), Salmonidae. Doklb Akad Nauk SSSR 1954; 97: 365-8

[16] Nolen SL, Wilhem J, Howick G. Factors influencing inorganic turbidity in a great plains reservoir. Hydrobiologia 1985; 123(2): 109-17.

[17] Helfman GS. In: Nielson LA, Johnson DL, Eds. Fisheries techniques. Bethesda, USA: Am Fish Soc, 1985; pp. 325-68.

[18] Sedell JR, Leone FN, Duval WS. Water transportation and storage of logs. In: W. R. Meehan, editor. Influences of forest and rangeland management on salmonid fishes and their habitats. Bethesda, MD, USA: AFS, 1994; P. 325-368

[19] Carper GL, Bachman RW. Wind resuspension of sediments in a Prairie Lake. Can J Fish Aquat Sci 1984; 41: 1763-7.

[20] Lahnsteiner F, Weisman T, Patzner RA. Composition of the ovarian fluid of 4 salmonid species: Onchoryncus mykiss, Salmo trutta $f$ lacustris, Salvelinu salpinus and Hucho hucho. Reprod Nutr Dev 1995; 35(5): 465-74.

[21] Lahnsteiner F, Weisman T, Patzner RA. Physiological and biochemical parameters for egg quality determination in lake trout, Salmo trutta lacustris. Fish Physiol Biochem 1998; 20: 375-88. 